\title{
Interstitial Laser Therapy of Benign Prostatic Hyperplasia
}

\author{
Rolf Muschter Hugh Whitfield \\ Department of Urology, Grosshadern University Hospital of Ludwig-Maximilians University, Munich, Germany
}

\section{Key Words}

Laser prostatectomy · Interstitial · Benign prostatic hyperplasia

\begin{abstract}
The objective of interstitial laser coagulation (ILC) of benign prostatic enlargement is to achieve a marked volume reduction and to decrease bladder outlet obstruction and lower urinary tract symptoms with minimal morbidity. Coagulation necrosis is generated well inside the adenoma by means of specifically designed laser applicators combined with either a Nd:YAG laser or a diode laser. Because the laser applicators can be inserted as deeply and as often as necessary, it is possible to coagulate any amount of tissue at any desired location while preserving adjacent structures such as the urethra. Postprocedural, the intraprostatic lesions result in secondary atrophy and regression of the prostate lobes, rather than sloughing of necrotic tissue. Several singlearmed and randomized studies indicated the effectiveness of interstitial laser coagulation of BPH-syndrome. Marked improvements in AUA score, peak flow rate, residual urine volume and prostate volume were reported. Pressure-flow studies demonstrated a sufficient decrease of the intravesical/detrusor pressure, urethral opening pressure and urethral resistance. Long-term results demonstrating sustained success for up to 3 years were reported on a series of 394 patients. ILC is suitable to debulk even large prostates and to treat highly ob-
\end{abstract}

\begin{tabular}{ll}
\hline KARGER & ( 1999 S. Karger AG, Basel \\
Fax +4161306 1234 & 0302-2838/99/0352-0147\$17.50/0 \\
$\begin{array}{l}\text { E-Mail karger@karger.ch } \\
\text { www.karger.com }\end{array}$ & Accessible online at: \\
http://BioMedNet.com/karger
\end{tabular}

structive patients. Therefore, ILC can be seen as a true alternative to TURP with certain advantages, such as almost no serious morbidity and with certain disadvantages, such as the need for postoperative catheterization. However, ILC can be done under local anesthesia and does not require hospitalization.

\section{Introduction}

Interstitial 'laserthermia' employing low-power laser radiation was first mentioned by Bown [1] in 1983. In 1984, interstitially applied laser radiation of lower power was experimentally tested for nonthermal photochemical effects in photodynamic therapy (PDT) [2]. Both concepts of interstitial laser therapy, the thermal and nonthermal approaches, were exclusively used to treat solid malignant tumors [3]. In the prostate, initial studies on interstitial laser therapy also focused on cancer treatment. Interstitial PDT experiments on transplanted prostate cancer cells were done as early as 1984 and 1985 [2, 4]. In 1988, Littrup et al. [5] and McNicholas et al. [6] performed animal experiments employing bare fibers to generate thermal lesions. The latter authors, who irradiated the prostate for treatment times from 200 to $1,500 \mathrm{~s}$ with $1-2 \mathrm{~W}$, found lesions of up to $1 \mathrm{~cm}$ in diameter [7, 8]. In 1992, the first patients with localized prostate cancer were treated before radical prostatectomy using the bare fiber technique $[8,9]$.
Priv.-Doz. Dr. Med. habil. Rolf Muschter

Department of Urology of Ludwig-Maximilians University of Munich Grosshadern University Hospital, Marchioninistr. 15

D-81377 Munich (Germany)

Tel. +49897095 4740, Fax +4989 7095 4746, E-Mail muschter@uro.med.uni-muenchen.de 


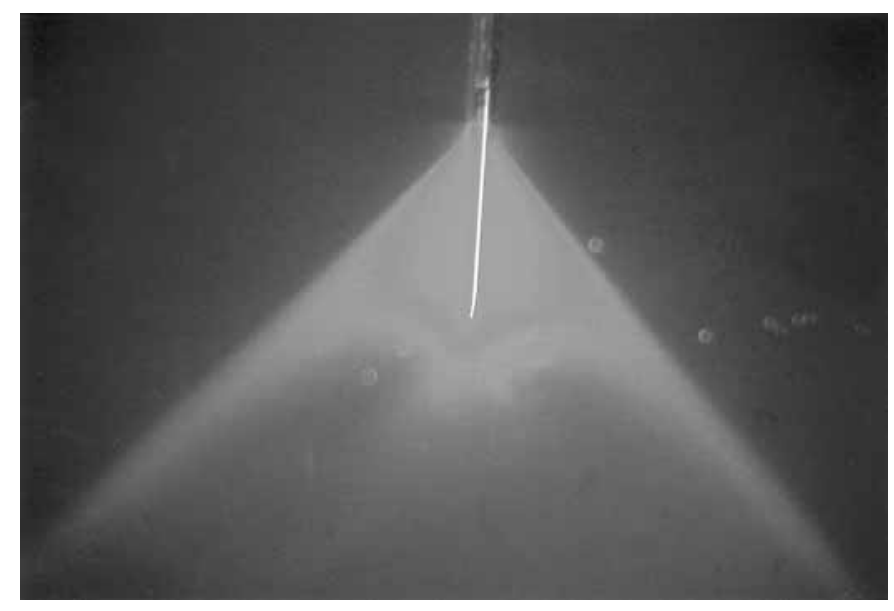

Fig. 1. ITT light guide, quartz glass fiber $600 \mu \mathrm{m}$, applicator $1.9 \mathrm{~mm}$ in diameter, $2 \mathrm{~cm}$ in length, $90^{\circ}$-cone shape radiation pattern (in air or water).

Interstitial laser coagulation (ILC) of benign prostatic hyperplasia (BPH) achieved with fibers specifically designed for this purpose was first mentioned by Hofstetter [10] in 1991, with the basic experiments and initial clinical results published by Muschter et al. [11] in 1992. Since then, several variations and technical and procedural developments have been introduced and tested in clinical trials [12-17].

The objective of ILC of BPH is to achieve a marked volume reduction, and to decrease urethral obstruction and both obstructive and irritative symptoms. Coagulation necrosis is generated well inside the adenoma, rather than at its urethral surface. Because the applicator can be inserted as deeply and as often as necessary, it is possible to coagulate any amount of tissue at any desired location. Postprocedural, the intraprostatic lesions result in secondary atrophy and regression of the prostate lobes, rather than sloughing of necrotic tissue $[13,16,18-21]$.

\section{Material and Methods}

Because of their relatively deep penetration in water, efficient volumetric heating permitting necrotic temperatures deep into tissues, and the ability to be delivered with flexible optical fibers, Nd:YAG lasers $(1,064 \mathrm{~nm})$ or diode lasers (approximately 800$1,000 \mathrm{~nm}$ ) are used for interstitial laser coagulation [11, 16, 18, 2127]. Recent experiments, however, demonstrated that the Ho:YAG laser $(2,120 \mathrm{~nm})$ is also suitable to generate interstitial lesions. This laser, however, does not generate a homogenous coagulation zone, but a central cavity with adjacent charring and peripheral coagulation [28].

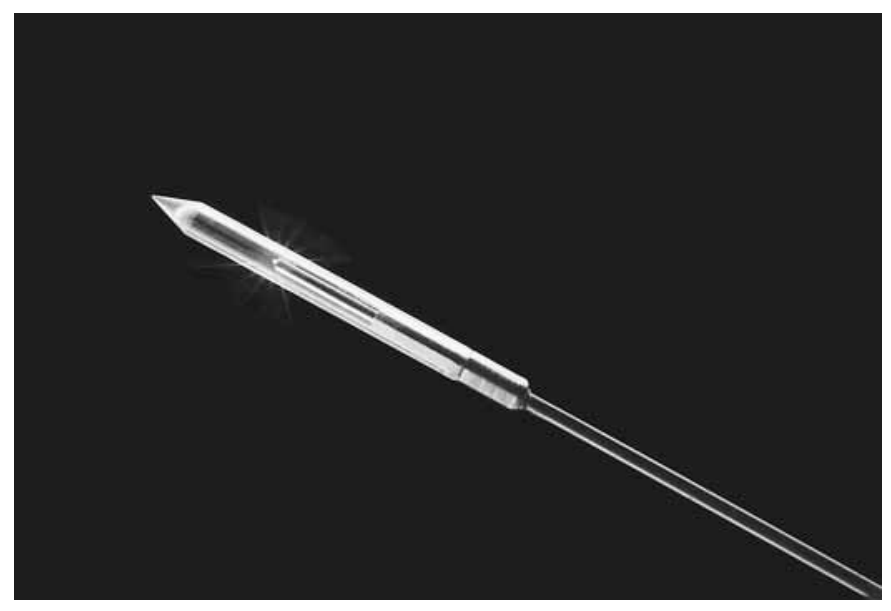

Fig. 2. Diffusor-Tip laser fiber $600 \mu \mathrm{m}$, applicator $2 \mathrm{~mm}$ in diameter, $2 \mathrm{~cm}$ in length, homogenous diffuse radiation over $1 \mathrm{~cm}$.

Fibers employed for ILC must emit laser radiation at a relatively low power density. One type of fiber emits the laser radiation circumferentially forward directed with a ring/cone-shaped beam profile (e.g. ITT light guide ${ }^{\mathrm{TM}}$, Dornier, Germering, Germany; fig. 1) [29], or Interstitial Laser Fiber, Baasel Lasertechnik, Starnberg, Germany; fig. 2). Another type of fiber is a cylindrical diffuser tip emitting in all directions from the whole length of the applicator (e.g. Diffusor$\mathrm{Tip}^{\mathrm{TM}}$, Indigo, Cincinnati, Ohio, USA; fig. 3). Other types of interstitial application systems or bare fibers were predominantly used experimentally [16-19, 23, 30, 31]. The optimal radiation parameters vary for different laser wavelength and applicator combinations $[11,16,23,25,28,30,31]$. Using constant laser power in the 5-7 W range, the maximal coagulation volume can be expected within approximately $10 \mathrm{~min}$ irradiation time without the risk of carbonization $[11,21,22,32]$. A more rapid heating by using higher laser power will reduce irradiation time, but increases the risk of carbonization $[22,33]$. For short irradiation times, however, high powers are tolerable. In this type of laser energy application, irradiation starts with a relatively high power to rapidly heat the tissue and coagulate the blood vessels (e.g. $20 \mathrm{~W}$ for $30 \mathrm{~s}$ or $50 \mathrm{~W}$ for $10 \mathrm{~s}$ ) [14, 21, 22, 34]. The laser power is then reduced repeatedly or continuously to maintain the temperature in the center of the lesion at a high level just below the carbonization threshold, and to allow further lesion growth. Online temperature monitoring by use of a thermocouple integrated into the application fiber allows further optimization by use of a feedback control $[15,35,36]$. Optical feedback systems can also detect any carbonization. If this occurs at the applicator, laser irradiation is automatically terminated. This prevents overheating and therefore potential thermal fiber damage.

ILC can be performed with local (e.g. periprostatic block) [34], regional (e.g. spinal), or systemic (e.g. analgosedation) anesthetic. The procedure is suitable to treat outpatients.

ILC can be done using the transurethral approach, in which the laser fiber is introduced from a cystoscope within the urethra [12, 13, $21,33,36-41]$, or the percutaneous (perineal) approach, in which the laser applicator is introduced through hollow needles in the perineum, guided by transrectal ultrasound [13, 21, 33, 42, 43]. 


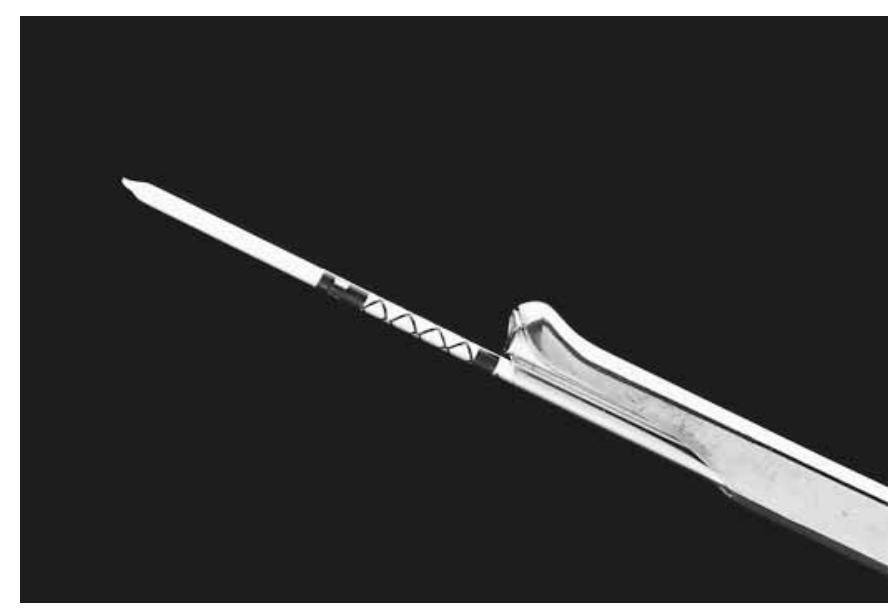

Fig. 3. Interstitial laser applicator, low-OH quartz glass fiber $600 \mu \mathrm{m}$, applicator $1.8 \mathrm{~mm}$ in diameter, $2 \mathrm{~cm}$ in length, $160^{\circ}$-cone shape radiation pattern (in air or water).

The commonly used transurethral ILC requires a cystoscope with a working channel of 5 to 6 French. An ideal instrument has a small separate working channel that ends at the level of the telescope for optimal stabilization of the fiber during puncture.

The total number of fiber placements is dictated by the total prostate volume and configuration. A general guideline would be one to two applicator placements for each estimated 5 to $10 \mathrm{~cm}^{3}$ of prostate tissue or approximately one to three placements per lobe per each $\mathrm{cm}$ of the prostatic urethra length. Individual placements of the laser fiber are spaced by about 0.5 to $1 \mathrm{~cm}$ and/or are performed at different angles and depths. In general, the sites for fiber placement are chosen where the bulk of hyperplastic tissue is found. The most apical punctures are performed in the prostatic urethra just proximal of the external sphincter (fig. 4) so that no apical tissue goes untreated. When punctures of the median lobe are done, the fiber is always advanced in the direction of the bladder to prevent subtrigonal coagulation. Fiber penetration of the capsule is almost impossible because of the limited penetration angle and depth achievable. In addition, the highly vascular nature of the prostate capsule acts as a heat sink and prevents potential coagulation of the capsule itself and adjacent structures, if the fiber is placed close. This was proven by magnetic resonance imaging studies performed during and after ILC [44-46] and by pathological studies when ILC was done before open prostatectomy [35]. However, one should avoid advancing the applicator dorsally because this prevents any theoretical risk of affecting the neurovascular bundles and rectum and yet there is little or no BPH tissue to treat.

\section{Clinical Results}

Several studies indicated the effectiveness of interstitial laser coagulation of BPH regarding all of the three characteristics of the disease: symptoms, obstruction and enlargement. All studies reported marked improvements

Interstitial Laser Therapy of Benign

Prostatic Hyperplasia

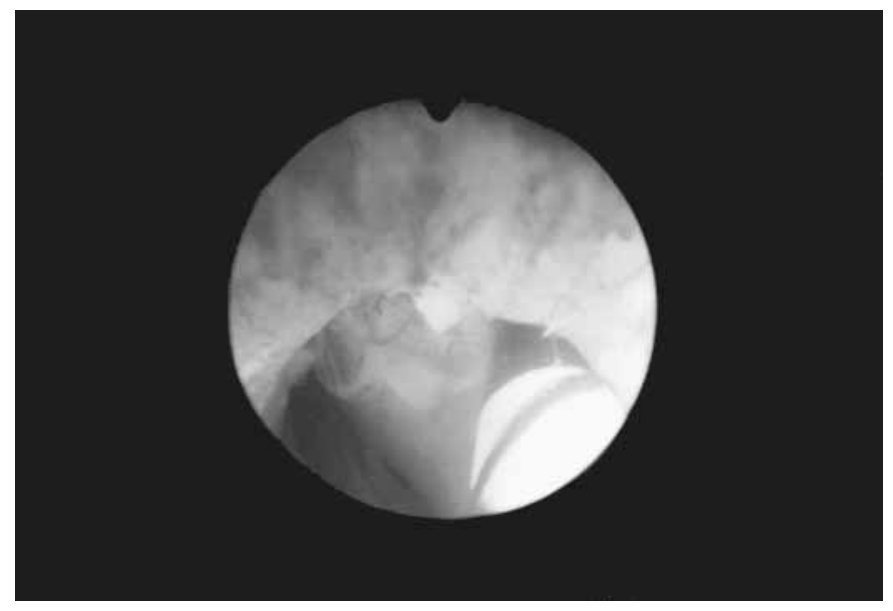

Fig. 4. ILC treatment of the right apex.

in AUA score, peak flow rate (table 1), residual urine volume and prostate volume (table 2) [12-14, 16, 19, 33, 36$38,40-43,47-49]$. The latter was not only demonstrated by measurements based on transrectal ultrasound, but also in studies using magnetic resonance imaging for volume measurements during follow-up [37, 45]. Analysis of possible factors predicting final success or failure clearly demonstrated the effect of the learning curve [50] and a correlation with the number of punctures per prostate volume. If less than one application per 5-7 $\mathrm{ml}$ of prostate volume was done, the results were less favorable [37, 42, $51,52]$.

Urodynamic parameters were also measured before and after ILC treatment [42, 43, 53, 54]. Pressure-flow studies demonstrated a sufficient decrease of the intravesical/detrusor pressure, urethral opening pressure and the urethral resistance. The detrusor pressure at Qmax. improved from 77.4 to $57.1 \mathrm{~cm} \mathrm{H}_{2} \mathrm{O}$ [53] in one and from 59 to $48 \mathrm{~cm} \mathrm{H}_{2} \mathrm{O}$ [43] in another study. The authors found this parameter 'normal' in $48 \%$ of their group of high-risk patients after ILC for severely obstructive BPH [42, 54].

Long-term results demonstrating sustained success on a series of 394 patients treated from 1991 through to 1994 were reported in 1997 (table 3) [34].

Prospective and randomized studies were also performed to compare the results achieved with ILC to those of other laser techniques $[43,55]$ and primarily transurethral resection of the prostate (TURP) [56-62]. In one series [56-58] 97 patients with severely symptomatic BPH were treated. 48 patients received ILC using standardized instrumentation (Nd:YAG laser, ITT light gui- 
Table 1. Symptom score and urinary peak flow changes after ILC: literature review

\begin{tabular}{|c|c|c|c|c|c|c|}
\hline \multirow[t]{2}{*}{ Author } & \multirow[t]{2}{*}{$\mathrm{n}$} & \multirow{2}{*}{$\begin{array}{l}\text { Follow- } \\
\text { up } \\
\text { months }\end{array}$} & \multicolumn{2}{|c|}{ AUA score } & \multicolumn{2}{|c|}{ Peak flow, $\mathrm{ml} / \mathrm{s}$} \\
\hline & & & preop & postop & preop & postop \\
\hline Arai et al. [37] & 70 & 6 & 18.9 & 7.7 & 6.7 & 10.0 \\
\hline de la Rosette et al. [36] & 25 & 3 & 20.6 & 6.9 & 9.1 & 20.3 \\
\hline Henkel et al. [42] & 35 & 12 & 21 & 8 & 5.3 & 10.0 \\
\hline Horninger et al. [43] & 12 & 12 & 29 & 6 & 8.3 & 16.9 \\
\hline Martov and Kilchukov [38] & 25 & 6 & 19.9 & 13.5 & 8.7 & 13.5 \\
\hline McNicholas and Alsudani [19] & 36 & 12 & 22 & 7 & 9.4 & 14.6 \\
\hline Muschter and Hofstetter $[13,33]$ & 239 & 12 & 25.4 & 6.1 & 7.7 & 17.8 \\
\hline Muschter et al. [47] & 48 & 12 & 31.0 & 2.3 & 9.4 & 19.7 \\
\hline Muschter et al. [12] & 112 & 6 & 20.9 & 7.9 & 8.0 & 14.2 \\
\hline Muschter et al. [14] & 42 & 3 & 22.1 & 4.2 & 8.2 & 24.9 \\
\hline Orovan and Whelan [40] & 16 & 3 & 16.3 & 5.8 & 8.8 & 11.9 \\
\hline Roggan et al. [16] & 27 & 2 & 14 & 5 & 8.0 & 13.0 \\
\hline Schettini et al. [41] & 20 & 3 & 22.6 & 9.2 & 7.9 & 15.0 \\
\hline Whelan [48] & 112 & 6 & 18.2 & 8.2 & 10.4 & 17.0 \\
\hline Zhenghua and Ciling [49]* & 78 & 3 & 22.5 & 8.5 & 9.8 & 16.5 \\
\hline
\end{tabular}

* ILC + bladder neck incision.
Table 2. Prostate volume changes after ILC: literature review

\begin{tabular}{llll}
\hline \multirow{2}{*}{ Author } & \multicolumn{2}{l}{ Prostate volume, ml } & \multirow{2}{*}{$\begin{array}{c}\text { \% volume } \\
\text { decrease }\end{array}$} \\
\cline { 2 - 3 } & preop & postop & \\
\hline Arai et al. [37] & 37.1 & 31.6 & 14.8 \\
Henkel et al. [42] & 67 & 43 & 35.8 \\
Horninger et al. [43] & 57.0 & 52.3 & 8.3 \\
Martov and Kilchukov [38] & 53.8 & 42.1 & 21.8 \\
Muschter and Hofstetter [13, 33] & 47.4 & 29.1 & 38.6 \\
Muschter et al. [47] & 47.1 & 27.5 & 41.6 \\
Roggan et al. [16] & 49 & 36 & 26.5 \\
Schettini et al. [41] & 66.6 & 49.0 & 26.4 \\
Whelan [48] & n.d. & n.d. & 26.1 \\
Zhenghua and Ciling [49] & 40 & 28 & 30.0 \\
\hline
\end{tabular}

n.d. $=$ No data.

* ILC + bladder neck incision.

Table 3. Long-term results of ILC in 394 patients treated in 19911994.

\begin{tabular}{lrccc}
\hline & Preop & $\begin{array}{l}\text { 1 year } \\
\text { postop }\end{array}$ & $\begin{array}{l}\text { 2 years } \\
\text { postop }\end{array}$ & $\begin{array}{r}\text { 3 years } \\
\text { postop }\end{array}$ \\
\hline AUA score & 24.2 & 6.3 & 6.8 & 7.9 \\
Peak flow, ml/s & 7.9 & 17.2 & 15.7 & 15.2 \\
\hline
\end{tabular}

$\mathrm{de}^{\mathrm{TM}}$ ), application technique (transurethral application with an 'integrated' cystoscope), and laser parameters (power stepwise reduced from 20 to $7 \mathrm{~W}, 3$ min total irradiation time per fiber placement) and were compared prospectively with 49 TURP patients. Within 12 months AUA score improved from 31.0 to 2.3 points (TURP: 31.1 to 3.5 points), life quality index from 4.7 to 0.6 points (TURP: 4.7 to 1.3 points), peak flow rate from 9.4 to $19.7 \mathrm{ml} / \mathrm{s}$ (TURP: $8.9-25.6 \mathrm{ml} / \mathrm{s}$ ), residual urine volume from 128 to $17 \mathrm{ml}$ (TURP: $167-7 \mathrm{ml}$ ), and prostate volumes from 47.1 to $27.5 \mathrm{ml}$ (TURP: $40.2-21.2 \mathrm{ml}$ ) on average. Four ILC patients were noted as treatment failures and received retreatment by transurethral resection. In a prospective randomized multicenter study a $10-\mathrm{W}$ diode laser system was used [59-61]. Six months followup in 166 patients [60] showed marked improvements in both groups, TURP, however, was significantly better (AUA score improving from 22.4 to 6.5 vs. ILC from 21.5 to 9.7 ; peak flow rate improving from 8.3 to $20.3 \mathrm{ml} / \mathrm{s}$ vs. ILC from 8.3 to $14.0 \mathrm{ml} / \mathrm{s}$ ). Another prospective randomized study using the $10-\mathrm{W}$ diode laser on 44 patients $(20$ ILK, 24 TURP) with a follow-up of 6 months demonstrated similar results [62]. The AUA score improved from 23 to 10.8 (TURP: 22.5-8.6) and the peak flow rate from 7.5 to $11.6 \mathrm{ml} / \mathrm{s}$ (TURP: $8.8-18.9 \mathrm{ml} / \mathrm{s}$ ). 


\section{Side Effects - Morbidity}

After ILC, a temporary increase of obstruction which can go along with urinary retention and temporary irritative symptoms such as urgency normally occurs. The latter was observed in approximately $5-15 \%$ patients [12$14,16,19,36-43,47-52,55-62]$. Postoperative catheterization, either transurethral or suprapubic, was required for an average of up to 18.3 days, but was much shorter in most studies with the catheter removed in more than $70 \%$ of patients within ten days $[12-14,16,19,36-43,47-52$, 55-62]. No study reported any occurrence of impotence or sustained incontinence [12-14, 16, 19, 36-43, 47-52, 55-62]. Retrograde ejaculation occurred occasionally, with reported rates varying from 0 to $11.9 \%$, very likely depending on the aggressiveness of treatment in total and of the bladder neck in particular [12-14, 37]. Urethral strictures or bladder neck strictures were reported in a frequency of approximately $5 \%$ for the first series of patients, but were not observed in subsequent series. Most complications, in particular the more serious ones, became less frequent or absent with increasing experience (table 4). Uncomplicated urinary tract infections occurred relatively frequent [12-14] and were probably related to postoperative catheterization. The need for repeated BPH treatment because of treatment failure occurred at varying rates between 0 and $15.4 \%$ (table 5) $[12-14,16,17,19,33,36-43,47,49]$ and $3.1 \%$ in the second and third year [34].

\section{Discussion}

An interpretation of the results of the different studies is interesting because it shows clearly the influence of the learning curve of both the operating urologist and the laser manufacturers on the clinical outcome, but also the role of patient selection. While the improvement of symptoms is quite in the same range in the different studies and comparable to TURP in randomized studies, the improvement of objective parameters shows a wider variation.

In some studies, very negative selected patients were treated. Henkel et al. [42, 54] included only severely obstructed high-risk patients not suitable for TURP, a high percentage of them being in urinary retention. Horninger et al. [43] treated only patients with prostate volumes of more than $50 \mathrm{ml}$.

For effective desobstruction, a large volume needs to be coagulated. As stated above (see results chapter), clinical results were better if a higher number of punctures per
Table 4. ILC complications: influence of treatment parameters and experience (percent values)

\begin{tabular}{llll}
\hline & $\begin{array}{l}\text { Muschter and } \\
\text { Hofstetter } \\
{[13,33]} \\
(\mathrm{n}=239)\end{array}$ & $\begin{array}{l}\text { Muschter } \\
\text { et al. [12] }\end{array}$ & $\begin{array}{l}\text { Muschter } \\
\text { et al. [14] }\end{array}$ \\
& 0.5 & 0 & $(\mathrm{n}=112)$ \\
\hline Blood transfusion & 0 & 0 & 0 \\
TUR syndrome & 2 & 0 & 0 \\
Clot retention & 0 & 0 & 0 \\
Incontinence & 1.7 & 0 & 0 \\
Bladder neck stricture & 5.4 & 0 & 0 \\
Urethral stricture & 1.5 & 0 & 0 \\
Epididymitis & 0 & 0 & 0 \\
Erectile dysfunction & 6.7 & 3 & 11.9 \\
Retrograde ejuaculation & 12.6 & 11 & 12.2 \\
Irritative symptoms & 35 & 27 & 16.5 \\
Urinary tract infection & & & \\
\hline
\end{tabular}

Table 5. ILC failure rates: literature review

\begin{tabular}{|c|c|c|c|c|}
\hline \multirow[t]{2}{*}{ Author } & \multirow[t]{2}{*}{$\mathrm{n}$} & \multirow{2}{*}{$\begin{array}{l}\text { Follow- } \\
\text { up } \\
\text { months }\end{array}$} & \multicolumn{2}{|c|}{ Retherapy } \\
\hline & & & $\mathrm{n}$ & $\%$ \\
\hline Arai et al. [37] & 70 & 6 & 5 & 7.1 \\
\hline de la Rosette et al. [36] & 25 & 3 & 0 & 0 \\
\hline Handke et al. [17] & 13 & 2 & 2 & 15.4 \\
\hline Henkel et al. [42] & 35 & 12 & 3 & 8.6 \\
\hline Horninger et al. [43] & 12 & 12 & 0 & 0 \\
\hline Martov and Kilchukov [38] & 25 & 6 & 0 & 0 \\
\hline McNicholas and Alsudani [19] & 36 & 12 & 0 & 0 \\
\hline Meagher [39] & 36 & n.d. & 3 & 8.3 \\
\hline Muschter and Hofstetter $[13,33]$ & 239 & 12 & 23 & 9.6 \\
\hline Muschter et al. [47] & 48 & 12 & 4 & 8.3 \\
\hline Muschter et al. [12] & 112 & 6 & 3 & 2.7 \\
\hline Muschter et al. [14] & 42 & 3 & 5 & 11.9 \\
\hline Orovan and Whelan [40] & 16 & 3 & 0 & 0 \\
\hline Roggan et al. [16] & 27 & 6 & 1 & 4 \\
\hline Schettini et al. [41] & 20 & 3 & 1 & 5 \\
\hline Zhenghua and Ciling [49]* & 78 & 3 & 0 & 0 \\
\hline
\end{tabular}

n.d. = No data.

* ILC + bladder neck incision.

volume were performed [37, 42, 43, 50]. This is a possible explanation for the contrast in peak flow improvements found with ILC in the randomized studies, when a $20-\mathrm{W}$ Nd:YAG laser or a 10-W diode laser was used. Whitfield $[59,60]$ and de la Rosette et al. [61] performed only an average of 6.7 punctures in an average $56 \mathrm{ml}$ prostate. 

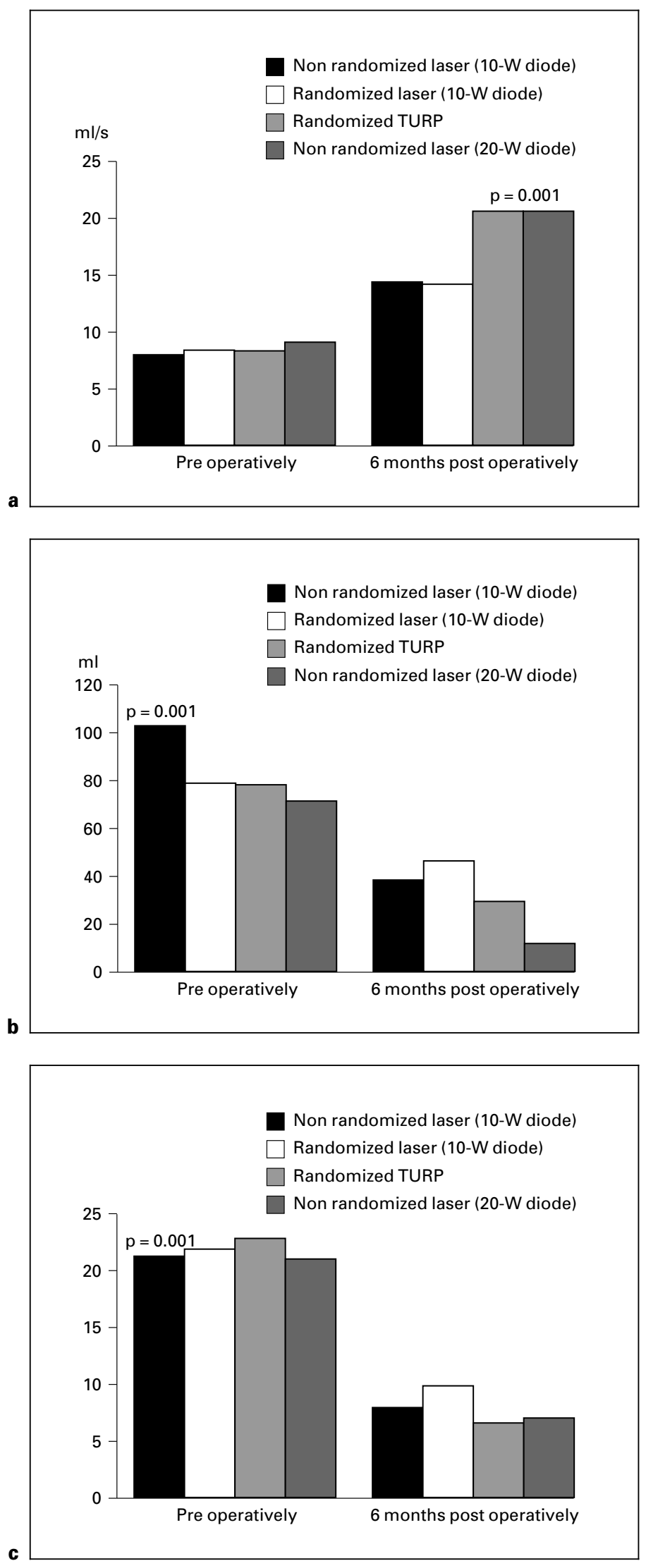

Another reason for the contrasting results is probably the learning curve. When Muschter and coworkers [5658] performed their prospective comparison to TURP, they had already treated more than 400 patients $[13,33$, 34]. In their first series of 239 patients, Muschter and Hofstetter [13, 33, 50] demonstrated in a multivariate analysis a correlation of the clinical improvements and the number of cases performed previously.

The effect of improved technology is the third possible reason. When comparing randomized and nonrandomized multicenter studies published by Muschter et al. [12], Whitfield [59, 60] and de la Rosette et al. [36, 61], all employing an 830-nm diode laser, a clear improvement of the clinical outcome regarding the peak flow rate and residual volume is seen when in a consecutive series a temperature-feedback controlled $20-\mathrm{W}$ model was used instead of the 10-W model employed in the first uncontrolled and randomized studies (fig. 5a, b). These findings are confirmed by pathological findings in the human prostate demonstrating that individual lesions became bigger with higher temperature and higher initial power [35] which was known already from animal experiments [14, 25]. Convincing clinical results were also achieved using a $\mathrm{Nd}$ :YAG laser with a 1-min treatment cycle with an initial power of $50 \mathrm{~W}$, accompanied by a marked reduction of treatment time [14].

When the symptomatic outcome is compared in the same studies [12, 36, 59-61], the difference between the different laser power is rather small (fig. 5c). At the first look, this is a surprise, but can be seen as another proof of the well-known fact that there is no correlation of symptoms, bladder outlet obstruction and prostate volume and that symptomatic relief, even if comparable to TURP in a randomized study, does not automatically serve as proof for desobstruction.

ILC is clearly suitable to debulk large prostates $[13,16$, $33,37,38,41-43,47-49]$ and to treat highly obstructive patients $[12-14,16,19,33,34,36-43,47-52,55-62]$. Therefore, ILC can be seen as a true alternative to TURP with certain advantages, such as almost no serious morbidity and with certain disadvantages, such as the need for postoperative catheterization. Furthermore, ILC can be done in local anesthesia and does not require hospitalization [34]. However, ILC also seems to be suitable as an

Fig. 5. Clinical outcomes of prospective nonrandomized and randomized multicenter studies using 830 -nm diode laser systems. a Urinary peak flow rate. b Residual urine volume. c AUA score. 
alternative to treat less obstructive but symptomatic BPH patients when performed with lower power or a smaller number of punctures. The tissue effects of this approach could be expected to be similar to those achieved by lowenergy transurethral microwave thermotherapy (TUMT) or transurethral needle ablation (TUNA). Because of less coagulation volume and less concomittant edema, the postoperative increase of obstruction would be less and would probably also compare to TUMT and TUNA, thus eliminating long postoperative catheterization, although this remains to be proven. However, the existing data suggest ILC to be adaptable to treat all different types of BPH syndrome, lower urinary tract symptoms with or without obstruction and with or without prostate enlargement.

\section{References}

1 Bown SG: Phototherapy of tumors. World J Surg 1983;7:700-709.

2 McPhee MS, Thorndyke CW, Thomas G, Tulip J, Chapman D, Lakey WH: Interstitial applications of laser irradiation in hematoporphyrin derivative-photosensitized Dunning R3327 prostate cancers. Lasers Surg Med 1984; 4:1984;93-98.

3 Bown SG: New approaches to local destruction of tumours: Interstitial laser hyperthermia and photodynamic therapy; in Svassand LO (ed): Future Trends in Biomedical Applications of Lasers. SPIE Proc 1991;1525:325-330.

4 Camps JL Jr, Powers SK, Beckman WC Jr, Brown T, Weissman RM: Photodynamic therapy of prostate cancer: An in vitro study. J Urol 1985;134:1222-1226.

5 Littrup PJ, Lee F, Borlaza GS, Sacknoff EJ, Torp-Pedersen S, Gray JM: Percutaneous ablation of canine prostate using transrectal ultrasound guidance. Invest Radiol 1988;23:734739.

6 McNicholas TA, Charig C, Steger AC, Bown SG: Interstitial laser coagulation of the prostate: An experimental study (abstracts issue) Lasers Med Sci 1988; 3:abstr 446.

7 McNicholas TA, Steger AC, Bown SG, O'Donoghue N: Interstitial laser coagulation of the prostate: Experimental studies; in Watson GM, Steiner RW, Pietrafitta JJ (eds): Lasers in Urology, Laparoscopy, and General Surgery. SPIE Proc 1991;1421:30-35.

8 McNicholas TA, Pope AJ, Timoney A, Lynch MJ, Parkinson MC, O’Donoghue N: Hyperthermia of the prostate by interstitial laser coagulation. J Urol 1992;147:345A.

9 McNicholas TA, Pope AJ, Timoney A, Lynch MJ, Parkinson MC, O'Donoghue N: Interstitial laser coagulation of the prostate: Experimental and clinical studies. J Urol 1992;147: 210A.

10 Hofstetter A: Interstitielle Thermokoagulation (ITK) von Prostatatumoren. Lasermedizin 1991;7:179.

11 Muschter R, Hofstetter A, Hessel S, Keiditsch E, Rothenberger K-H, Schneede P, Frank F: Hi-tech of the prostate: Interstitial laser coagulation of benign prostatic hypertrophy; in Anderson RR (ed): Laser Surgery: Advanced Characterization, Therapeutics, and Systems III. SPIE Proc 1992;1643:25-34.

Interstitial Laser Therapy of Benign

Prostatic Hyperplasia
12 Muschter R, de la Rosette JJMCH, Whitfield H, Pellerin J-P, Madersbacher S, Gillatt D: Initial human clinical experience with diode laser interstitial treatment of benign prostatic hyperplasia. Urology 1996;48:223-228.

13 Muschter R, Hofstetter A: Technique and results of interstitial laser coagulation. World $\mathrm{J}$ Urol 1995;13:109-114.

14 Muschter R, Sroka R, Perlmutter AP, Schneede $\mathrm{P}$, Hofstetter A: High power interstitial laser coagulation of benign prostatic hyperplasia. J Endourol 1996;10(suppl 1):S197.

15 de la Rosette JJMCH, Muschter R, Lopez MA: Interstitial laser coagulation in the treatment of $\mathrm{BPH}$ using a tissue adaptive laser system. J Endourol 1996;10(suppl 1):S93.

16 Roggan A, Handke A, Miller K, Müller G: Laser induced interstitial thermotherapy of benign prostatic hyperplasia: Basic investigations and first clinical results. Minim Invas Med 1994;5:55-63.

17 Handke A, Roggan A, Andreesen R, Miller K: Laserinduzierte interstitielle Thermotherapie (LITT) bei BPH. Urologe [A] 1994;33:S81.

18 Johnson DE, Cromeens DM, Price RE: Interstitial laser prostatectomy. Lasers Surg Med 1994;14:299-305.

19 McNicholas T, Alsudani M: Interstitial laser coagulation therapy for benign prostatic hyperplasia. SPIE Proc 1996;2671:300-308.

20 Muschter R, Hofstetter A, Hessel S, Keiditsch E, Schneede P: Interstitial laser prostatectomy: Experimental and first clinical results. J Urol 1992;147:346A.

21 Muschter R, Hessel S, Hofstetter A, Keiditsch E, Rothenberger K-H, Schneede P, Frank F: Die interstitielle Laserkoagulation der benignen Prostatahyperplasia. Urologe [A] 1993;32: 273-281.

22 Muschter R, Perlmutter AP: The optimization of laser prostatectomy. II. Other lasing techniques. Urology 1994;44:856-861.

23 Muschter R, Perlmutter AP, Anson K, Jahnen P, Vargas Stüve JC, Razvi HA, Sroka R, Hofstetter A, Vaughan ED Jr: Diode lasers for interstitial laser coagulation of the prostate; in Anderson RR (ed): Lasers in Surgery: Advanced Characterization, Therapeutics, and Systems V, SPIE Proc 1995;2395;77-82.

24 Henkel TO, Niedergethmann M, Alken P: Laser-induced interstitial thermotherapy (LITT): In vitro and in vivo studies. J Endourol 1995; 9(suppl 1):S56.
25 Muschter R, Hessel S, Jahnen P, Yalavac H, Hofstetter A: Evaluation of different laser wavelengths and application systems for LITT; in Müller G, Roggan A (eds): Laser-Induced Interstitial Thermotherapy. Bellingham, SPIE Press, 1995, pp 212-223.

26 Muschter R, Hofstetter A, Anson K, Perlmutter AP, Vaughan ED Jr: Nd:YAG and diode lasers for interstitial laser coagulation of benign prostatic hyperplasia: Experimental and clinical evaluation. J Urol 1995; 153:229A.

27 Muschter R, Perlmutter AP, Anson K, Sroka R, Vargas Stüve JC, Jahnen P, Yalavac H, Razvi HA, Vaughan ED Jr, Hofstetter AG: Experimentelle Untersuchungen zur Eignung von Halbleiterlasern für die interstitielle Laserkoagulation der Prostate - Erste Ergebnisse. Lasermedizin 1995;11:150-156.

28 Sroka R, Muschter R, Perlmutter AP: Interstitial Holmium:YAG laser application: A new procedure for prostatic tissue ablation. J Urol 1997;157(suppl):41.

29 Hessel St, Frank F: Technical prerequisites for the interstitial thermo-therapy using the Nd:YAG laser; in Katzir A (ed): Optical Fibers in Medicine V. SPIE Proc 1201 1990;1201: 233-238.

30 Bhatta KM, Perlmutter A, Cho G, Morrison PR, Silverman SG, Jolesz FA, Loughlin KR: A new technique of subsurface and interstitial laser therapy using a diode laser (wavelength = $1,000 \mathrm{~nm}$ ) and a catheter delivery device. $\mathbf{J}$ Urol 1996;155:310A.

31 Slatkine M, Mead D, Konwitz E, Johnson ED: A neodymium:YAG fiber delivery system for interstitial photothermal therapy; in Watson GM, Steiner RW, Johnson DE (eds): Lasers in Urology, SPIE Proc 1994;2129:56-66.

32 Sroka R, Perlmutter AP, Martin T, Muschter R: LITT on canine prostates: An in-vivo study to compare the effects of different wavelengths. SPIE Proc 1996;2671:335-338.

33 Muschter R, Hofstetter A: Erfahrungen mit der interstitiellen Laserkoagulation in der Therapie der benignen Prostatahyperplasie. Lasermedizin 1994;10:133-139.

34 Muschter R, Schneede P, Müller-Lisse U, Fink HU, Perlmutter AP, Sroka R, Hofstetter AP: Interstitial Nd:YAG laser therapy of the prostate: Long-term results and new developments. J Urol 1997;157(suppl):42. 
35 Lopez M, Vargas JC, Muschter R, Perlmutter AP: The size of prostatic interstitial laser lesions can be controlled by temperature. J Urol 1997;157(suppl):41.

36 de la Rosette JJMCH, Muschter R, Lopez MA, Gillatt D: Interstitial laser coagulation in the treatment of benign prostatic hyperplasia using a diode-laser system with temperature feedback. Br J Urol 1997;80:433-438.

37 Arai Y, Ishitoya S, Okubo K, Suzuki Y: Transurethral interstitial laser coagulation for benign prostatic hyperplasia: Treatment outcome and quality of life. Br J Urol 1996;77:93-98.

38 Martov AG, Kilchukov ZI: Interstitial laserinduced coagulation of BPH: 6 months followup. J Endourol 1996;10(suppl 1):S191.

39 Meagher M: Interstitial laser prostatectomy. J Endourol 1996;10(suppl 1):S192.

40 Orovan WL, Whelan JP: Neodynium YAG laser treatment of $\mathrm{BPH}$ using interstitial thermotherapy: A transurethral approach. J Urol 1994;151:230A.

41 Schettini M, Diana M, Fortunato P, Mauro M, Vincenzoni A, Tavani M, Gallucci M: Results of interstitial laser coagulation of the prostate. J Endourol 1996;10(suppl 1):S191.

42 Henkel TO, Greschner M, Luppold T, Alken P: Transurethral and transperineal interstitial laser therapy of BPH; in Müller G, Roggan A (eds): Laser-Induced Interstitial Thermotherapy. Bellingham SPIE Press, 1995, pp 416-425.

43 Horninger W, Janetschek G, Pointner J, Watson G, Bartsch G: Are TULIP, interstitial laser and contact laser superior to TURP? J Urol 1995; 153:413A.

44 Heuck A, Müller-Lisse U, Muschter R, Schneede P, Scheidler J, Hofstetter A, Reiser M: Einsatz der Magnetresonanz-Tomographie für die Darstellung der interstitiellen Laserkoagulation bei der benignen Prostatahyperplasie: Erste Erfahrungen. Lasermedizin 1995;11:2733.
45 Müller-Lisse UG, Heuck AF, Schneede P, Muschter R, Scheidler J, Hofstetter AG, Reiser MF: Postoperative MRI in patients undergoing interstitial laser coagulation thermotherapy of benign prostatic hyperplasia. J Comput Assist Tomogr 1996;20:273-278.

46 Müller-Lisse U, Heuck A, Stehling MK, Frimberger M, Thoma M, Schneede P, Muschter R, Hofstetter A, Reiser M: MRT-Monitoring vor, während und nach der laserinduzierten Thermotherapie der benignen Prostatahyperplasie. Erste klinische Erfahrungen. Radiologe 1996; 36:722-731

47 Muschter R, Ehsan A, Stepp HG, Hofstetter A Clinical results of LITT in the treatment of benign prostatic hyperplasia; in Müller G, Roggan A (eds): Laser-Induced Interstitial Thermotherapy. SPIE Press, Bellingham, 1995, pp 434-442.

48 Whelan JP: Interstitial laser coagulation of the prostate: Transrectal ultrasound findings 3 months after treatment. J Urol 1997; 157(suppl):435.

49 Zhenghua G, Ciling C: ITT Combined with vaporized incision for treatment of BPH. J Endourol 1996;10(suppl 1):S192.

50 Muschter R, Hofstetter A: Interstitial laser therapy outcomes in benign prostatic hyperplasia. J Endourol 1995;9:129-135.

51 Arai Y, Kanba T, Ishitoya S, Okubo K, Shichiri Y, Suzuki Y: Interstitial laser coagulation for benign prostatic hyperplasia: Preliminary clinical results. Int J Urol 1995;2:104-109.

52 Arai Y, Ishitoya S, Okubo K, Suzuki Y: Interstitial laser coagulation for benign prostatic hyperplasia: 1-year follow-up and analysis of patient profile linked to clinical response. J Urol 1996;155:319A.

53 Zellner M, Muschter R: Initiale urodynamische Ergebnisse nach interstitieller Laserkoagulation der Prostata bei benigner Hyperplasie. Lasermedizin 1994;10:141-144.
54 Henkel TO, Greschner M, Luppold T, Rassweiler J, Alken P: Perineal interstitial laser of the prostate (PILP); in Bown SG, Escourrou J, Frank F, Geschwind HJ, Godlewski G, Laffitté F, Scherer HH (eds): Medical Applications of Lasers II. SPIE Proc 1994;2327:293-295.

55 Muschter R, Hofstetter A: Laserbehandlung der benignen Prostatahyperplasie. Urologe [A] 1994;33:281-287.

56 Muschter R, Ehsan A, Baumhackl D, Stepp HG: Interstitielle Laserkoagulation versus transurethrale Resektion: Ergebnisse eines prospektiven Vergleichs. Urologe [A] 1995; 34(suppl 1):S74.

57 Muschter R: Interstitial laser therapy. Curr Opin Urol 1996;6:33-38.

58 Muschter R, Hofstetter A: Thermocoagulation au laser de l'adénome de la prostate par voie interstitielle. Ann Urol (Paris) 1997;31:27-37.

59 Whitfield HN: The use of an interstitial diode laser (Indigo) in laser prostatectomy: A randomized, controlled, prospective study. J Endourol 1995;9(suppl 1):S149.

60 Whitfield HN: A randomized prospective multicenter study evaluating the efficacy of interstitial laser coagulation. J Urol 1996;155: 318A.

61 de la Rosette JJMCH, Muschter R, Whitfield HN, Gillatt DA, Vicente JR, Fay R, Barett D, Reese J, Block NL, Costello AJ: Report of a prospective multicenter randomized study evaluating interstitial laser coagulation for BPH. J Endourol 1996;10(suppl 1):S125.

62 Fay R, Chan SL, Kahn R, Sharlip I, Altman R: Initial results of a randomized trial comparing interstitial laser coagulation therapy to transurethral resection of the prostate. J Urol 1997; 157(suppl):41. 